\title{
Supervision of the Imported Soil Beans Containing Insects by Semarang Agricultural Quarantine
}

\author{
Dentata Gama Ashari ${ }^{*}$, Rinitami Njatrijani ${ }^{2}$, Edy Sismarwoto $^{3}$ \\ \{dentashr@gmail.com ${ }^{* 1}$, rinitami@live.undip.ac.id ${ }^{2}$, edy.sismarwoto@live.undip.ac.id $\left.{ }^{3}\right\}$
}

Fakultas Hukum, Universitas Diponegoro, Jl. Prof. H. Soedarto, S.H., Semarang, Indonesia $50275^{1}$

\begin{abstract}
Horticultural Import Control needs to be carried out strictly by the government. Products that enter Indonesia must be good for consumption. The case of the dangerous insect Khapra beetle (Trogoderma Granarium) occurred in tens of tonnes of imported Sudanese peanuts found in Tanjung Emas Port. The case was investigated with the first problem of how to carry out the supervision of Class I Barantan Semarang, and the second was how the measurements carried out by Class I Semarang Barantan to imported Sudanese Nuts containing Khapra Beetles in Semarang City. This study uses a normative juridical methodology with an empirical approach, using primary data and secondary data which are then analyzed using qualitative descriptive techniques. The results showed that the monitoring of peanuts containing insects at Tanjung Emas Port has been carried out in accordance with the policies of Semarang City Class I Officials and in accordance with the applicable laws and regulations. The surveillance measures that have been carried out by Barantan Class I Semarang on the import of Peanuts from the country of Sudan resulted in the Rejection of Non-conformity Notifications and Automatic Detection.
\end{abstract}

Keywords: Horticultural Import Supervision, Trogoderma Granarium, Quarantine Actions.

\section{Introduction}

Food is a basic human need whose fulfillment is for human right guaranteed in the 1945 Constitution of the Republic of Indonesia.

Food commodities in Indonesia that are favored by the people are the Fresh Origin of Plants (PSAT) category, one of which is Horticultural Food Products. Horticultural Products is one type of fresh food that is regulated in Indonesia.

One category of Fresh Horticultural Products that is favored by Indonesian people is Peanuts, both peanuts for consumption or peanuts for industrial raw materials. As a result of these high needs, Peanut demand to other countries continues to rise, but on the other hand, Peanut production in Indonesia tends to fall with low production so that the dependence on imports to meet growing needs is greater.

Before entering Indonesia, Horticultural Food Products must pass administrative requirements and document suitability. After going through the next administrative phase, following the required stages in accordance with statutory provisions. The suitability of the document will determine whether the product is appropriate for distribution in the community or not. 
Efforts to guarantee legal certainty that have been made by the government, then law enforcement must be done. One of them is through supervision. According to M. Manullang, understanding of Supervision is a process to determine what work has been carried out, assess it and correct it if necessary with the intention that the implementation of the work is in accordance with the original plan.[1]

Supervision conducted by Barantan Class I Semarang can be suspected whether supervision has been carried out accordingly since it is the first line of defense in protecting and preserving animal biological resources from the threat of pests and quarantine plant diseases which greatly influences the potential production and productivity of agricultural commodities and other biological resources. This can be proven by the presence of food products that do not meet the expectations of the community and are not suitable for food because they contain something harmful.

Food cases that do not meet the provisions and endanger the attack on Imported Food Products. Food Products in the form of Imported Horticulture Products that occurred during 2019 were the entry of imported Peanuts from the State of Sudan which contained dangerous insects called the Khapra Beetle (Trogoderma granarium). At the end of November 2019, Barantan Class I Semarang detected five containers or around 95 tons of imported Sudanese Peanuts that entered through the Port of Tanjung Emas in Semarang were again exposed to Khapra beetle insects (Trogoderma Granarium). Tens of tons of imported Peanuts were attacked by beetles Khapra (Trogoderma Granarium) lives alighted and lays eggs in the bean and attaches to the walls of containers and is very large. The majority of the Khapra Beetles on imported peanuts are still larvae, light brown. The condition of some of the Peanuts in the sack has broken.

Khapra beetle (Trogoderma Granarium) is a warehouse insect, including a type of dangerous insects that have very high destructive power. These insects target the commodity beans and can survive for decades without eating. According to the Regulation of the Minister of Agriculture of the Republic of Indonesia Number 93/Permentan/OT.140/12/2011 concerning Types of Quarantine Plant Disturbing Organisms (hereinafter referred to as OPTK), these insects are included in Group 2 Category A1.[2] Remembering the WTO organization which has declared Indonesia to be a free country of the Khapra Beetle since 2009.

Violations that occur in the case of imports of horticultural products in the form of imported Peanuts have been contaminated in the warehouse of the country of origin. Then, the question is how can these Peanuts enter to Indonesia. Even though the administrative requirements have been met, the facts in the field are not in accordance with what is expected by the community. In this situation, it is clear that the importer loses time and cost as well as the impact of Indonesia in the future.

Considering that the Indonesian Government cannot limit horticultural imports, because Indonesia has entered into an agreement in free trade. In this case, the government can only tighten the door to import and import risk analysis in the country of origin. invitation and standard set by Indonesia, namely the Indonesian National Standard (SNI).

From the description above, the problems that can be arranged include:

1. What is the supervision policy of Semarang Class I Agricultural Quarantine Agency on the Import of Horticultural Products in the form of Peanuts that contain insects in the Port of Tanjung Emas?

2. What control measures should be taken by Semarang Class I Agricultural Quarantine Agency on the Import of Horticultural Products in the form of Peanuts containing Khapra Beetle insects in the City of Semarang? 


\section{Research Method}

The research methodology used in this study is the normative juridical methodology with the empirical approach method. The research specification in writing this paper is descriptiveanalytical, that is, this research will disclose applicable laws and regulations related to the implementation occurring in the field based on the results of the survey as well as with legal theories that occur in the object of research.[3]

\section{Results and Discussion}

\subsection{The monitoring policy and its implementation by Semarang Class I Agricultural Quarantine Agency on the import of Peanuts containing Khapra beetle insects}

Class I Agricultural Quarantine (Barantan) Semarang always monitors the implementation of quarantine. In supervising Barantan Class I Semarang based on policies:

1. Law Number 18 of 2002 concerning Food

2. Law Number 13 of 2010 concerning Horticulture

3. Law Number 21 of 2019 concerning Animal, Fish and Plant Quarantine

4. Government Regulation of the Republic of Indonesia Number 14 of 2002 concerning Plant Quarantine

5. Regulation of the Minister of Agriculture of the Republic of Indonesia Number 271 of 2006 concerning Procedures for Implementing Certain Plant Quarantine Actions by Third Parties

6. Regulation of the Minister of Trade No. 60 of 2012 concerning Provisions on the Import of Horticultural Products

7. Regulation of the Minister of Agriculture No. 51 of 2015 concerning Types of Quarantine Plant Disturbing Organisms

8. Regulation of the Minister of Agriculture No. 55 of 2016 concerning Supervision of Food Safety of Fresh Food Importation from Plants

9. Regulation of the Minister of Agriculture No. 16 of 2017 concerning Recommendations on the Import of Horticultural Products

Supervision of quarantine as mandated in Law Number 21 of 2019 concerning Animal, Fish and Plant Quarantine which is carried out to protect the preservation of biological natural resources from the threat of Quarantine Animal Disease (HPHK) and Quarantine Plant Disturbance Organisms (OPTK) and regulations other regulations. What is meant by Animal, Fish and Plant Quarantine according to Article 1 of Law Number 21 of 2019 reads:[4]

"Animal, Fish and Plant Quarantine, hereinafter referred to as Quarantine, is a system of preventing the entry, exit, and distribution of quarantine pests and animal diseases, quarantine fish pests and diseases, quarantine plant-disturbing organisms, and supervision and/or control of food safety and food quality, feed safety and feed quality, Genetically Engineered Products, Genetic Resources, Biological Agents, Invasive Foreign Types, Wild Plants and Animals, and Endangered Plants and Animals that are included in the distribution, distribution from one Area to another, and/or issued from the territory of the Unitary Republic of Indonesia." 
It is the obligation of the Barantan Class I Semarang to conduct quarantine when there is a Carrier Media imported in the territory of Indonesia contaminated by HPHK, HPIK and OPTK. Based on Article 5 of Law Number 21 of 2019, Quarantine Organization is based on the level of adequate state protection against HPHK, HPIK and OPTK. Under Article 6, it is stated that the inclusion of carrier media for the first time or if there is a change in the status of the disease in the country of origin of quarantine measures is based on sanitary and phytosanitary agreements.

Any horticultural product that enters into Indonesian territory must be subject to quarantine. The implementation of quarantine actions is regulated in Law Number 21 of 2019 Article 28 that the implementation of quarantine actions is carried out prior to import or export customs notification submitted and carried out using the risk category.

One of the many Peanuts imported by the people of Indonesia is Peanuts Imported from Sudan, considering that Sudan is the 5th largest producer of Peanuts in the World. However, the fact is that the import of Peanuts at the Port of Tanjung Emas in Semarang is not in line with the expectations of the Indonesian people. Imported Peanuts that should be directly circulated and traded must be carried out beforehand, because they are not fit for consumption because they contain dangerous insects. detrimental to importers because it takes time and costs.

Based on the case, it is the authority (competence) of Class I Semarang Officials to conduct quarantine supervision and actions based on Law Number 21 of 2019 on Animal, Fish and Plant Quarantine, Government Regulation Number 14 of 2002, regulations on IWRM and regulations on RIPH. 8P Quarantine Action is regulated in Article 16 of Law Number 12 of 2019 and Article 72 regulates the supervision and control of security and quality of food and feed, PRG, SDG, Biological Agents, Invasive Foreign Types, wild plants and animals which are also rare which are integrated with quarantine measures at the point of entry and expenditure. The implementation of Barantan Class I Semarang in supervising the 8P quarantine action on imported horticultural products in the form of peanuts containing insects from Sudan according to Law Number 21 of 2019 includes:

\subsubsection{Examination} of:

Based on Article 37 Examination as referred to in article 16 paragraph (1) letter a consists

a. Administrative examination and document suitability; and

b. health inspection, food safety test, food safety test, food quality test, and/or food quality test.

\section{a. Carry out administrative checks and document suitability}

Before the Quarantine Action is carried out, service users must fulfill the requirements and completeness of documents and other obligations. Administrative Examination is carried out by functional officials by taking into account the type of media and the importing Administrative documents which must include:
a. Phytosanitary Certificate
b. SIP (Entry Permit)
c. Import permit/PIB
d. Cargo manifest/high school
e. PSAT import description 
f. PSAT security certificate

g. Treatment Certificate

h. Packing list

i. Invoice

j. Recommendation from the Director General of Animal Husbandry

k. BL (Bill of Lading)

Importers or those authorized (usually EMKL) needs to provide those documents in order to successfully import the product successfully. Documents submitted online and must already have a username and password to be able to log into the Barantan Class I Semarang website. [5]

One of the Peanut Importers from Sudan is CV Langgeng Anugerah Makmur which already fulfilled the requirements and suitability of administrative documents. Specific mandatory requirements for the import of PSAT are Peanuts attaching printed documents in the form of:

a. Phytosanitary (PC) is a plant health certificate from the country of origin that issues the Quarantine of the country of origin. In the case of imported peanuts, it has fulfilled the requirements for this administration document, which is the issuance of peanut plant health certificates from the Quarantine of Sudan.

b. CoA (Certificate of Analysis) is an additional requirement for importing peanuts which is a certificate of analysis. Because peanuts are for human consumption, there must be a CoA to determine whether they are Good for Consumption. The certificate of analysis contains the results of the laboratory testing of the bean, its pesticide content, bacteria and its heavy metal content

c. Prior Notice is a type of PSAT certificate, attached at the time of import and issuing the country of origin.

d. A hot certificate is a substitute for CoA if the laboratory has not been registered in the Quarantine of the country of origin. The issuing Hot Certificate is the government of the country of origin or the laboratory of the country of origin.

\section{b. Health check up}

Inspection of Imported Peanuts from Sudan entering Indonesia is carried out by visual inspection method by Plant Quarantine Officials. Health checks of Peanuts are carried out on a conveyance, beginning with the opening of the container and then opening it on the Peanut wrapping sack. Furthermore, taking and submitting Peanut Seed commodity samples amounted to $0.5 \mathrm{~kg}$ with a random sampling method that is from one sack to another using ganco to ascertain the condition of the Peanuts and put into plastic which will be carried out health checks at Class I Labantan Laboratory Semarang with microscopic testing methods during 1 hour.

Based on the information from the health examination, the physical condition of the Peanut (Arachis hypogaea) carrier media is 95 tons of good seeds but some of them have been damaged and destroyed and are not free from harmful OPTK namely the Khapra beetle insects (Trogoderma Granarium) which are still alive and are very numerous. Then, the Plant Quarantine Officer immediately issued five containers containing 95 Tons of the Peanut from the Port by issuing a certificate for the Quarantine Treatment (KT-2).

\subsubsection{Exile}

Based on Article 41 paragraph (1), it is states that: 
"Alienation and Observation as included in Article 16 paragraph (1) letter b and letter c are conducted to detect certain HPHK, HPIK and OPTK which due to their nature require a long time, facilities, and/or special conditions."

Imported Peanuts from Sudan do not need to be exiled because based on physical examination it has been found that insects can be seen directly with the eye or visually so it does not require a long time. Alienation and Observation is only done for the entry of seeds or seeds. non-seeds will only be removed from the port to be treated and not sequestered.

Barantan Class I Semarang does not need to do Simap (Alienation and Observation) because it already has a registered laboratory so it is sufficient to do detention before being given further treatment and wait for the results of the lab for 2-3 weeks and then can be released immediately. Exile is only done if Barantan Class I Semarang does not yet have a registered Laboratory.

\subsubsection{Observation}

Pursuant to Article 42 paragraph (1), Observations are done at the Import and Export Points or at the designated Quarantine Installation.

Based on Government Regulation Number 14 of 2002 concerning Plant Quarantine, which states that if during exile and observation, the result will turn out according to following criteria:[6]

a. The carrier media is not free from OPTK Category I, whether rotten or damaged, then it will be rejected;

b. The carrier is not free from OPTK Category II, then it will be further treated;

c. The carrier is free from OPTK, then it can be released carried out.

Observation of Peanut Imports is in accordance with the place of entry, namely at the Tanjung Emas Port of Tanjung Emas Port Quarantine (TPK). Observation is carried out on Peanut carrier media in containers. (possessed) Insect Khapra beetle still alive allegedly from the country of Sudan. The Khapra beetle is a type of insect that belongs to Group II, which is a type of insect that can be released from the Carrier by treatment. The Class I Semarang Quarantine Plant Quarantine Officer who will recommend the OPTK contained in the peanut will then be treated based on an analysis of the risk of insect species.

\subsection{4 treatment}

Based on Article 43 which states that:

1) the treatment is carried out to free or disinfect Carrier Media or other actions that are preventive, curative and/or promotive.

2) Treatment is needed if after examination or alienation and observation it turns out that Carrier Media:

a. Contracting or suspected contracting HPHK or HPIK, or;

b. Not free or suspected of not being free from OPTK.

3) The treatment can only be done after the Carrier Media is examined physically first and is considered not to interfere with subsequent observations and examinations.

The treatment for imported peanuts that are suspected of not being free from OPTKini is in accordance with the type and risk analysis of the OPTK namely Khapra Beetle which according to the rules must be given fumigation treatment with methyl bromide. 
The implementation of fumigation treatment is carried out at the Plant Quarantine Installation (IKT) and is not carried out entirely by the Plant Quarantine Officer, the authority in this case is delegated by a 3rd party that has been registered and part of Barantan Class I Semarang. As a 3rd Party, Submitting requirements as a fumigator to the local Barantan then the local Brantan submits to the center, then an evaluation of the fumigator audit and the feasibility of the fumigator is conducted.

IKT is determined by the Head of the Agricultural Quarantine Agency and is valid every 1-2 years, and can be extended. There is also another place that is a recommendation from the Head of the local Quarantine Center, valid every 3 months and can be extended. However, IKT or other places every 6 months must be monitored and evaluated whether the IKT is still suitable for plant quarantine. It is not allowed to carry out arbitrary checks, there must be a place determined by the head of the body.

Private companies that fumigate imported Peanuts that contain Khapra Beetles are the SemarangCV Mitra Indo Mandiri MKT Depot.

Fumigation treatment is guided by Permentan Number 37 of 2009 concerning the use of pesticides with active ingredients of Methyl Bromide for quarantine treatment and preshipment treatment. Peanuts containing Khapra beetle insects were fumigated at a dose of 80 $\mathrm{g} / \mathrm{m} 3$ of Fumigan for $2 \times 24$ hours at temperatures $>200 \mathrm{C}$. In accordance with procedures established by the Agricultural Quarantine Agency and stated in the treatment column on the Phytosanitary Certificate.

Fumigation is done by closing the container using an airtight plastic curtain. Fumigation rooms must be gas-tight. Fumigation treatment is done by spraying (gassing) with the pesticide Methyl Bromide ( $\mathrm{CH} 3 \mathrm{Br}$.). The gas release phase is the most dangerous stage during the fumigation process. To that end, the Fumigator must ensure that the fumigation area is safe and the implementation of gas release must follow the established procedures. Fumigation treatment measures against Peanuts amounting to 95 tons from the Sudanese country infested by the Khapra beetle.

The results of methyl bromide fumigation on Khapra beetles for 2 x 24 hours were successful. The Khapra beetle in the Peanut is dead, Peanut is free from OPTK. Then after the fumigation treatment the peanut is safe for consumption, but the condition of the Peanut is partially damaged and destroyed.

\subsubsection{Detention}

Under Article 44, detention is carried out to secure Carrier Media under the supervision of the Quarantine Officer.

Under Article 70 it states that:

(1) Quarantine actions as referred to in Article 16 paragraph (1), the documents are issued, and if necessary, Quarantine seals are installed by Quarantine Officials in accordance with their area of competence.

(2) Every person is prohibited from opening, releasing, deciding, disposing, or damaging the Quarantine seal as referred to in paragraph (1) without permission from the Quarantine Officer in accordance with the area of his competence.

Detention is carried out by installing seals on imported Peanuts stating that the commodity is under the supervision of a plant quarantine officer according to Law Number 21 of 2019, in this case peanuts cannot be directly circulated to the public because they contain Khapra beetle insects and must be treated first in accordance with statutory provisions. 


\subsubsection{Rejection}

Under Article 45 it states that:

(1) Rejection as referred to in Article 16 paragraph (1) letter $\mathrm{f}$ is carried out to prevent the spread of HPHK, HPIK, or OPTK and to prevent human health problems and damage to living natural resources.

(2) as referred to in paragraph (1), the Carrier Media that is inserted into, removed from, or entered from an Area to another Area within the territory of the Unitary State of the Republic of Indonesia is carried out if:

a. the inspection is carried out on a conveyance at the Entry point:

1. Contracting HPHK, HPIK, or not free from OPTK; or;

2. Types of entry prohibited.

b. Requirements are not met

c. After being treated as referred to in Article 43 cannot be cured and/or disinfected from HPHK, or HPIK, or cannot be released from OPTK; or

d. After the deadline for fulfilling the required documents, the entire requirements that must be completed are not fulfilled.

Imported peanuts are not rejected, because in the administrative examination the Peanut has fulfilled the requirements and completeness of the document and after being given fumigation treatment with methyl bromide, it turns out that the imported Peanut can be freed from Khapra beetle insects.

\subsubsection{Extermination}

Based on Article 50 which states that:

(1) In the event that the Carrier Media entered does not find the owner, examination will be carried out on the Carrier Media.

(2) If the results of the inspection referred to in paragraph (1) turn out to be Carrier Media:

a. Contracting HPHK, HPIK, or not free of OPTK; and/or;

b. After being treated, it cannot be cured and/or disarmed.

(3) Annihilation as referred to in paragraph (2) letter a is the responsibility of the Central Government.

Peanuts Imported from Sudan No extermination is done. Annihilation is only done if the Carrier Media is rejected by Barantan Class I Semarang.

\subsubsection{Liberation}

Under Article 55 it states that:

(a) Exemption as referred to in Article 16 paragraph (1) letter $\mathrm{H}$ is carried out by issuing:

a. Certificate for importation; or

b. Health certificate or sanitation certificate for expenditure.

(b) Exemption as referred to in paragraph (1) of Carrier Media inserted into or included from one Area to another within the territory of the Unitary State of the Republic of Indonesia is carried out if it turns out:

a. After checking as referred to in Article 37 letter b, it is not infected with HPHK, HPIK or free from OPTK; 
b. After exile and observation as referred to in Article 41, are not infected with HPHK, HPIK, or free from OPTK; or

c. After the treatment as referred to in Article 43, can be cured from HPHK, HPIK or can be released from OPTK.

The Semarang Class I Agricultural Quarantine Center issues a plant quarantine/safety certificate for Fresh Origin of Plants (PSAT) called the KT-9 letter, stating that based on the Quarantine, Animal, Fish and Plant Laws and the Food Law and its implementation regulations and the results of plant quarantine measures/PSAT safety supervision turned out to be 95 tons of imported Peanuts from Sudan in the form of seeds fulfilling all the requirements stipulated for the inclusion of carrier media and can be freed from the Khapra Beetle OPTK as well as fulfilling all the stipulated PSAT requirements. the territory of the Unitary Republic of Indonesia. Peanuts are declared safe for consumption and can be distributed to the public.

\subsection{Supervision actions that should be taken by the Semarang Class I Agricultural Quarantine Agency against the Khapra Beetle insect}

\subsubsection{Insect Khapra Beetle (Trogoderma Granarium)}

The Khapra beetle named Trogoderma granary Everts has the synonym Trogoderma affrum Priesner, included in the order Coleoptrea, family Dermestidae (Hinton 1975). The khapra beetle was first reported for its presence in India but has now been found in several countries in Asia, Australia, Europe and America.

Trogoderma granarium is a warehouse pest that is at risk of causing high economic losses. This pest is a type of insect Class II Category A1 Quarantine Plant Disturbant in Java. This means that these insects do not yet exist in Indonesia and are among the insects that can be released from the Carrier by treatment. This pest is found in many imported commodities, especially for grains and can survive for years without eating.

Trogoderma granarium reported by Lowe et al. (2000) is one of the hundred most damaging warehouse pest insects in the world. In October 1970, the khapra beetle was found in Indonesia in imported rice which was stored in a warehouse for several months in Semarang, and suffered heavy damage and had become flour (Dano 1997).

The ability of this khapra beetle is naturally only in a short and limited distance because the image cannot fly. Imago and larvae in the khapra beetle can be spread with the help of wind and can be expanded with the help of infested materials and means of transportation.

\subsubsection{Fumigation with Methyl Bromide for Plant quarantine treatment}

In accordance with the provisions of the applicable laws and regulations, carrier media that are suspected of not being free from OPTK must be treated. Such treatment can be in the form of physical, biological or chemical treatment.

Fumigation is a form of chemical treatment. Treatment actions by fumigation are generally chosen if the OPTK that is targeted for treatment includes insect pests, mites, nematodes, or mollusks. Fumigation aims to free Carrier Media in the form of plants from pest insects, mites, nematodes, or the Moluska.

Provisions of Article 16 Paragraph (1) of Law No. 21/2019 states that the existence of plant quarantine measures 8P. Fumigation, including treatment, is the authority (competency) of plant quarantine officers.

However, in its further regulation, the law does not require that the authority to carry out the quarantine action be carried out entirely by the plant quarantine officer. In certain cases, 
the authority can be delegated to a third party of its implementation. The delegation of authority can be seen in Article 72 PP No. 14/2002.

According to Minister of Agriculture Regulation No. 271/Kpts/HK.310/4/2006 concerning the requirements,[7] and procedures for carrying out certain plant quarantine actions by third parties in point a considering that in the framework of the smooth implementation of certain plant quarantine actions. The implementation of fumigation by third parties may only be carried out by fumigation companies that have been registered by the Agricultural Quarantine Agency. The requirements referred to in Article 6 Paragraph (3) of the aforementioned Permentan are listed in the Fumigation Company Registration Guidelines, which are legally binding and must be carried out by fumigation companies in the context of plant quarantine treatment measures.

Methyl bromide is a colorless, odorless, non-combustible gas at normal temperatures easily, liquid under certain pressure, so it is supplied and stored in liquid form under pressure in a tube.

Fumigation with methyl bromide is one of the standard treatment used for quarantine and pre-shipment purposes because it can kill pests in various stages up to 100 percent.

\subsubsection{Supervised actions that should be carried out on Peanuts that contain Khapra Beetles}

Following up on the findings of the Khapra beetle insect and the effect of methyl bromide on imported horticultural products, especially Peanuts, Barantan Class I Semarang synergistically conducted an audit of all Horticultural Products, especially grains that entered the territory of the Republic of Indonesia. This audit was carried out to examine the process as a whole and identify critical points that enable product quality and safety standards not being met. Based on the audit results stated that the Khapra Beetle (Trogoderma Granarium) is a warehouse insect from the country of origin including a dangerous insect species in the world that has a destructive power and results in very high economic losses. Quarantine treatment of Khapra beetle insects with methyl bromide fumigation also has an effect on commodities. Peanuts belong to the type of commodity that absorbs fumigants, especially at high doses, can produce noticeable sulfur stains, especially when the product is processed.

According to the statement of Mr. Heri Widarta S.P., M.Sc as the Coordinator of the Class I Plant Quarantine Functional Office in Semarang, an officer must follow up and anticipate the findings of the Khapra Beetle. In carrying out supervision of the entry of imported horticultural products, especially Peanuts from the country of Sudan for the future, Semarang Class I Class performs the actions:

1. Rejection, Rejection that refuses to import Horticultural Products, especially Peanuts originating from the Country of Sudan. Semarang Class I Quarantine Center will automatically reject the import of Peanuts from Sudan, even though the administrative requirements are complete and fulfilled. Given the case of Peanuts Imported from Sudan which contains high-risk insects occur repeatedly and can endanger the lives of Indonesian people.

According to the Regulation of Minister of Agriculture Number 51 of 2015 concerning Type of Quarantine Plant Disturbing Organism, Khapra Beetle is a type of insect category A1 group 2.[8] Category A1 means that the OPTK has never been found in Indonesia, Group 2 is all OPTK that can be released from the Carrier by treatment . According to the Khapra Beetle's literature, it can survive decades without eating. So that it can survive, especially in Indonesia, the conditions are very supportive, namely in Indonesia there are many seeds. 
2. Notification of Non-compliance, Barantan Class I Semarang sends a notification of Non-compliance (Notification of Non Compliance). They will notify the head office of the country of origin, that the peanut seeds are infested with the Khapra beetle. It is likely that the Agricultural Quarantine Agency will notify or warn the country of origin that there may not be imports from there.

Barantan Class I Semarang also made a circular letter to be aware of the entry of Khapra Beetles from endemic countries, especially those of Africa and South Central Asia, as Khapra Beetle endemic countries, delivered on September 10th to all UPTs throughout Indonesia.

3. Automatic Detection, Barantan's action policy, which is called automatic detection. It is an action that states that once a commodity has entered Indonesia, for example, the peanut commodity from Sudan will be directly fumigated, there will be no need for more inspection and warning. to trading partner countries so that they do not ignore the provisions of Barantan Class I Semarang and vice versa. They pay attention to our provisions, namely once entered must be allowed to import beans but do not import pests.

\section{Conclusion}

1. Supervision of imported horticultural products in the form of Peanuts containing Khapra Beetles in the Port of Tanjung Emas Semarang has been carried out in accordance with the policies of the Semarang Class I Agricultural Quarantine and in accordance with the procedures of the Law and other relevant regulations. The form of supervision starts from import licensing to monitoring the treatment of the 8P Act. Quarantine measures to free OPTK Khapra Beetles by fumigation methyl bromide at a dose of $80 \mathrm{~g} / \mathrm{m}$ for 48 hours. As a result, the Khapra Beetle died and the Peanut was safe for distribution to the community.

2. Khapra beetles are dangerous insects that have a high risk of loss to the country's economy. They includes insect species category A1 Group 2 based on Permentan 51 of 2015 concerning OPTK Types. The Khapra beetle will die when treated with Methyl Bromide Fumigation. Methyl Bromide is a pesticide that is very limited and dangerous and has a bad influence on commodities and humans. With this pesticide, Barantan Class I Semarang will take action if found importers will import Peanuts from Sudan, which resulting in automatic rejection, Non-compliance Notification, and automatic detection.

\section{References}

[1] S. Murhaini, Manajemen Pengawasan Pemerintahan Daerah. Yogyakarta: Pustaka Pelajar, 2014.

[2] Regulation of the Minister of Agriculture of the Republic of Indonesia Number 93/Permentan/OT.140/12/2011 concerning Types of Quarantine Plant Disturbing Organisms. .

[3] Z. Ali, Metode Penelitian Hukum. Jakarta: Sinar Grafika, 2013.

[4] Law Number 21 of 2019 concerning Animal, Fish and Plant Quarantine. . 
[5] Interview with Heri Widarta, Coordinator of the Plant Quarantine Functional Office of Agriculture Quarantine Class I Semarang (Semarang, 30 January 2020). .

[6] Government Regulation of the Republic of Indonesia Number 14 of 2002 concerning Plant Quarantine. .

[7] Regulation of the Minister of Agriculture of the Republic of Indonesia Number 271 of 2006 concerning Procedures for Implementing Certain Plant Quarantine Actions by Third Parties. .

[8] Regulation of the Minister of Agriculture No. 51 Year 2015 concerning Types of Quarantine Plant Disturbing Organisms. . 